\title{
The Inclusion of Ethnic Minority Patients and the Role of Language in Telehealth Trials for Type 2 Diabetes: A Systematic Review
}

Talia Isaacs ${ }^{1 *}, \mathrm{PhD}$; Daniel Hunt ${ }^{2 *}, \mathrm{PhD}$; Danielle Ward ${ }^{3}, \mathrm{MPH}$; Leila Rooshenas ${ }^{4}, \mathrm{PhD}$; Louisa Edwards ${ }^{4}, \mathrm{PhD}$

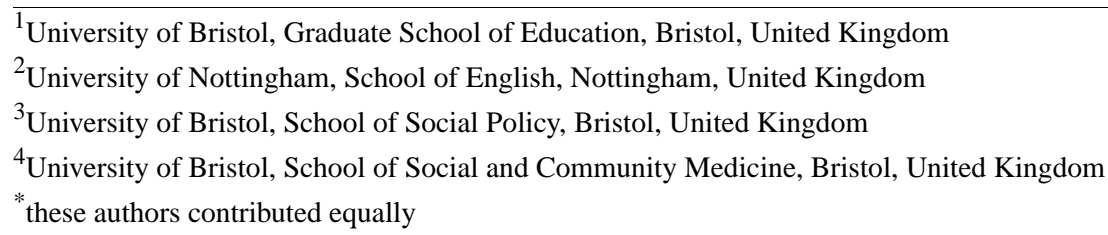

\section{Corresponding Author:}

Talia Isaacs, PhD

University of Bristol

Graduate School of Education

35 Berkeley Square

Bristol, BS8 1JA

United Kingdom

Phone: 441173314312

Fax: 441173317391

Email: talia.isaacs@bristol.ac.uk

\begin{abstract}
Background: Type 2 diabetes is a serious, pervasive metabolic condition that disproportionately affects ethnic minority patients. Telehealth interventions can facilitate type 2 diabetes monitoring and prevent secondary complications. However, trials designed to test the effectiveness of telehealth interventions may underrecruit or exclude ethnic minority patients, with language a potential barrier to recruitment. The underrepresentation of minorities in trials limits the external validity of the findings for this key patient demographic.
\end{abstract}

Objective: This systematic review examines (1) the research reporting practices and prevalence of ethnic minority patients included in telehealth randomized controlled trials (RCTs) targeting type 2 diabetes and the trial characteristics associated with recruiting a high proportion of minority patients, and (2) the proportion of included RCTs that report using English language proficiency as a patient screening criterion and how and why they do so.

Methods: Telehealth RCTs published in refereed journals targeting type 2 diabetes as a primary condition for adults in Western majority English-speaking countries were included. Ethnically targeted RCTs were excluded from the main review, but were included in a post hoc subgroup analysis. Abstract and full-text screening, risk of bias assessment, and data extraction were independently conducted by two reviewers.

Results: Of 3358 records identified in the search, 79 articles comprising 58 RCTs were included. Nearly two-thirds of the RCTs (38/58) reported on the ethnic composition of participants, with a median proportion of $23.5 \%$ patients (range 0\%-97.7\%). Fourteen studies (24\%) that included at least 30\% minority patients were all US-based, predominantly recruited from urban areas, and described the target population as underserved, financially deprived, or uninsured. Eight of these 14 studies (57\%) offered intervention materials in a language other than English or employed bilingual staff. Half of all identified RCTs (29/58) included language proficiency as a participant-screening criterion. Language proficiency was operationalized using nonstandardized measures (eg, having sufficient "verbal fluency"), with only three studies providing reasons for excluding patients on language grounds.

Conclusions: There was considerable variability across studies in the inclusion of ethnic minority patients in RCTs, with higher participation rates in countries with legislation to mandate their inclusion (eg, United States) than in those without such legislation (eg, United Kingdom). Less than $25 \%$ of the RCTs recruited a sizeable proportion of ethnic minorities, which raises concerns about external validity. The lack of objective measures or common procedures for assessing language proficiency across trials implies that language-related eligibility decisions are often based on trial recruiters' impressionistic judgments, which could be 
subject to bias. The variability and inconsistent reporting on ethnicity and other socioeconomic factors in descriptions of research participants could be more specifically emphasized in trial reporting guidelines to promote best practice.

Trial Registration: PROSPERO International Prospective Register of Systematic Reviews: CRD42015024899; http://www.crd.york.ac.uk/PROSPERO/display_record.asp?ID=CRD42015024899 (Archived by WebCite at http://www.webcitation.org/6kQmI2bdF)

(J Med Internet Res 2016;18(9):e256) doi: 10.2196/jmir.6374

\section{KEYWORDS}

telemedicine; telehealth; type 2 diabetes; diabetes mellitus; ethnic minorities; trial recruitment; systematic review; language; English proficiency; health communication

\section{Introduction}

Diabetes, a chronic metabolic condition, is on the rise, placing growing resource pressures on health care systems worldwide [1]. With the risk of developing diabetes increasing with obesity, sedentary behavior, and age, type 2 diabetes accounts for roughly $90 \%$ of diabetes cases. Behavioral changes (eg, diet, exercise), coupled with medication aiming to lower blood sugar levels and blood pressure, can reduce the risk of developing diabetes-related complications [2]. Due to its prevalence and the benefits of effective disease management, type 2 diabetes is frequently targeted in studies aiming to promote lifestyle modification through behavioral interventions and education [3].

Telehealth, broadly defined as remote health care delivery using technology [4], can partially alleviate the growing pressures associated with aging populations and rising rates of chronic conditions [5]. Technological advances have led to the availability of wide-ranging telehealth options to support patients as an alternative or supplement to traditional outpatient care, with presumed benefits including cost reduction, increasing convenience and access, and promoting patient self-management [6,7]. For example, diabetes-related telehealth services often involve platforms for measuring and communicating blood glucose information and receiving feedback from an automated system or remote professional. Other services involve structured self-management education or peer or motivational support [8]. Although findings from randomized controlled trials (RCTs) testing the effectiveness of telehealth interventions have been mixed and tend to vary by condition, systematic reviews focusing on type 2 diabetes specifically have generally yielded positive results, including modest but significant improvements for glycemic control and favorable outcomes for patient quality of life and treatment satisfaction [8-15].

Due to its flexibility, telehealth has the potential to reach underserved patients who may experience difficulties accessing traditional health services [16,17]. This extends to ethnic minorities, who are particularly vulnerable to developing type 2 diabetes [18], tending to do so at a younger age and with a lower body mass index than the general population in Western countries [19]. In the United Kingdom, for example, South Asians have up to six times higher prevalence of type 2 diabetes compared to people from Caucasian backgrounds, with incidence up to three times higher in people of African or African-Caribbean descent [20]. Ethnic minority groups also experience poorer long-term outcomes for diabetes, such as worse glycemic control and higher rates of complications [21], even when patients have access to health care at minimal cost [22] and after adjusting for age and socioeconomic status $[19,23]$. Ethnic minorities may also experience impaired self-management and underuse services due to a combination of socioeducational factors, including a less developed understanding of diabetes, differing attitudes toward medication, culturally specific dietary practices, and/or language barriers to accessing care [13,24,25].

Despite having a higher incidence of diabetes, ethnic minority patients tend to be underrepresented in trials [26-28]. This means that they cannot receive the potential health benefits from trial participation [29,30], including access to improved treatments and closer monitoring during the trial period. In addition, studies are not able to adequately assess the effectiveness of new treatments for these higher-need groups. For example, telehealth technologies trialed on a disproportionately Caucasian sample may not be generalizable to a diverse patient demographic, with implications for the service-level adoption of such interventions $[31,32]$. Low participation rates of ethnic minority diabetes patients have been reported in systematic reviews focusing on telehealth interventions, although the ethnic composition of the recruited sample is often unreported. In a 2006 review, only eight of 26 included studies reported on the ethnic composition of trial participants, of which the median proportion of ethnic minority patients was 39\% (range 5\%-100\%) [33]. Similarly, two 2014 reviews found that only half of 16 included studies [34] and four of nine included studies [3] reported on the ethnic makeup of the recruited sample, with variable minority participation across these studies (range 15\%-100\% and range $24 \%-100 \%$ of total participant population, respectively).

Although the results of these reviews $[3,33,34]$ are revealing in terms of prevalence and research reporting practices, they have several limitations. First, the included studies were restricted to a narrow range of computer-based telehealth interventions-a subset of the wide variety of the telehealth technologies available. For example, they excluded trials that were phone-based or included glucose monitoring, which are pervasive in telehealth diabetes research [15]. Next, two reviews included studies that targeted both type 1 and type 2 diabetes $[33,34]$. Because ethnic minorities are not disproportionately affected by type 1 diabetes, it is important to identify the prevalence of minority participants in studies that exclusively focus on type 2 diabetes. Third, two of the reviews included trial designs other than RCTs [3,33], with different designs potentially affecting the type of patients who had opted to take 
part (eg, due to time commitments) [35,36] in addition to not providing the same design safeguards against bias [37]. Finally, both 2014 reviews included studies that specifically recruited from one or more ethnic minority communities [3,34]. The inclusion of these ethnically targeted studies likely inflated ethnic minority patient prevalence estimates relative to studies recruiting from the general population. This systematic review addresses these limitations by focusing on telehealth RCTs targeting type 2 diabetes in adults recruited from the wider patient population. The telehealth medium used in the RCTs was not restricted in order to more comprehensively survey research reporting practices across the range of technologies. A central aim of this review was to explore the barriers and facilitators to ethnic minority inclusion in telehealth RCTs.

Among the factors that could affect ethnic minority participation in RCTs, language and literacy are often identified as potential obstacles [26,31]. Of foreign-born people living in the United States, 29\% reported speaking English "not well" or "not at all" [38] compared to more than 12\% in Australia [39]. In England and Wales, nearly $19 \%$ of adults from the four largest ethnic minority communities were estimated to speak little or no English [40]. Poor language skills are also related to higher levels of undiagnosed diabetes and to difficulties accessing services [13,41]. Ensuring that patients have the requisite language ability to understand the conditions for trial participation is an ethical imperative in all research (eg, obtaining informed consent). Because communication is a key part of the treatment in telehealth trials, language could act as a barrier to telehealth's ability to provide more accessible, equitable modalities for delivering care. For example, telehealth interventions often necessitate basic literacy skills (eg, understanding and inputting written text) or enhanced communication skills (eg, communicating on the phone with no access to nonverbal cues), potentially barring the participation of patients without adequate language skills to engage with the intervention in the absence of translation or interpretation services [42].

There is a pressing need to examine the role of language in telehealth interventions, especially in countries where a sizeable portion of the population has limited ability in the official language. This is particularly the case for conditions such as type 2 diabetes, to which ethnic minority communities are particularly vulnerable. Yet little is known about whether and how patients are screened for language proficiency or literacy nor the extent to which these factors are cited among the participant inclusion or exclusion criteria in telehealth RCTs targeting type 2 diabetes [30,43]. In light of these gaps, the goals of this systematic review were to investigate (1) the research reporting practices and prevalence of ethnic minority patients included in telehealth RCTs targeting type 2 diabetes and trial characteristics associated with successful minority patient recruitment, and (2) the proportion of included RCTs that report English language proficiency as a participant-screening criterion and how and why proficiency was assessed.

\section{Methods}

This review followed the Cochrane Collaboration's handbook on conducting systematic reviews [44] and the Preferred Reporting Items for Systematic Reviews and Meta-Analyses (PRISMA) guidelines [45]. Full methodological details, including MEDLINE search strategy terms, are reported in the published protocol [46].

\section{Search Strategy and Study Screening and Selection}

The search, which was conducted in late August 2015, included studies published from January 1, 2000 to July 31, 2015 using MEDLINE, PsycINFO, EMBASE, CINAHL, and CENTRAL. Keywords and inclusion criteria from recent related reviews were examined [15,34,47,48] and a medical librarian was consulted to verify the search strategy (eg, keywords, choice of databases). Abstract and full-text screening were independently performed by two reviewers (LE, KB, or DW), with discrepancies resolved through discussion. Multiple outputs from the same dataset were linked for included studies and imported into Endnote X7.

Included studies were peer-reviewed English-language journal articles on telehealth RCTs recruiting adult ( $\geq 18$ years) type 2 diabetes patients from Western countries where English is both an official and the majority language (ie, Australia, Canada, Ireland, New Zealand, United Kingdom, United States). All other research designs and publication types were excluded, as were RCTs that included type 1 or gestational diabetes patients, or that had explicitly targeted one or more ethnic minority groups in their recruitment strategy. Interventions could comprise any telehealth medium designed to treat or improve type 2 diabetes as the primary condition. Studies focusing on secondary diabetes-related complications (eg, retinopathy) or mental health were excluded as were telehealth interventions solely targeting health professionals rather than patients.

\section{Data Collection}

The data extraction form Multimedia Appendix 1 was developed using Cochrane guidelines [44] to describe study details, participant demographics, and intervention characteristics. Outcome data were extracted using Microsoft Excel and independently checked by two reviewers (DH, DW). The Cochrane Collaboration's risk of bias (ROB) tool [49] was adapted to assess all 79 included articles using Cochrane's Review Manager software (RevMan, The Cochrane Collaboration, Copenhagen, Denmark). Two of three authors (LE, DH, DW) independently evaluated each article for low, unclear, or high ROB, with discrepancies resolved through discussion. The assessment criteria were random sequence generation (selection bias), allocation concealment (selection bias), blinding of participants and personnel (performance bias), blinding of outcome assessment (detection bias), incomplete outcome data (attrition bias), selective reporting (reporting bias), and other sources of bias (other bias).

Due to the nature of telehealth interventions, patient and personnel blinding is generally unfeasible. Hence, for the purpose of this review, high risk of performance bias was interpreted as situations where unblinded research personnel 
interacted with participants across study groups, allowing for differential treatment. Assessment of detection bias focused on primary outcome detection. Studies that used an objective primary outcome measure (eg, laboratory-based blood test, administrative record of number of hospital visits) were assessed as low ROB because knowledge of participants' allocation is unlikely to seriously affect the outcome. Conversely, studies where the primary outcome was subjectively assessed (eg, self-report measures) were deemed high ROB.

\section{Data Analysis}

Data analysis of included studies addressed the following primary outcomes:

1. Proportion of studies that report on the ethnic composition of recruited participants and, where available, the overall prevalence of ethnic minority patients (between-study median and range);

2. Characteristics of studies that recruit a high proportion $(\geq 30 \%)$ of ethnic minority participants (eg, telehealth medium, access to translation);

3. Proportion of studies that include English language proficiency or reading and writing literacy as a participant-screening criterion and, where available, the ways in which proficiency/print literacy is operationalized as a screening criterion; and

4. Language-related reasons for patient exclusion, if given (eg, informed consent, lack of resources).

In line with categorizations of race and ethnicity in the United States census [50] and conceptualizations of nonwhite or non-Caucasian respondents in other majority English-speaking countries (eg, United Kingdom [51]), ethnic minorities were defined as those of nonwhite ethnicity, including Hispanics, who may or may not be newcomers to the host country. In the case of studies reporting only the proportion of white patients recruited, all other participants were assumed to be ethnic minorities. In other studies that listed the proportion of participants belonging to an "other" group, "other" was interpreted as patients from an ethnic minority background not specified elsewhere in the study.

A narrative synthesis [52] was conducted to examine the characteristics of RCTs that reported a $30 \%$ or greater threshold of ethnic minority participants as a proportion of the total sample (considered relatively high), which is in line with the median prevalence of minority recruitment reported in earlier related reviews $[3,33,34]$. We would also note that this threshold is close to the proportion of ethnic minorities in the United States population. In the 2015 census, the "white alone, not Hispanic or Latino" category was reported at $61.6 \%$, which implies that the remaining $38.4 \%$ are ethnic minorities [53]. After systematically extracting and tabulating the data, groupings and textual descriptions were used to explore heterogeneity within those studies and between studies with higher and lower proportions of ethnic minority participants. Exploration of relationships in the data was iteratively conducted to reveal factors that may promote or impede ethnic minority recruitment.

Finally, a post hoc subgroup analysis was conducted for studies that had explicitly targeted one or more ethnic minority groups as part of their recruitment strategy and that had been excluded from the systematic review for that reason only [54-65]. This additional retrospective analysis of ethnically targeted studies was undertaken to further examine recruitment strategies and features of trials that specifically recruited ethnic minority participants. This analysis involved the same methods as the synthesis described previously, but did not contribute to calculations reported in the main analysis.

\section{Results}

\section{Study Selection}

The search yielded 2332 records after removing duplicates, which were submitted to abstract screening. After assessing 212 full-length articles for eligibility, 79 articles, consisting of 58 discrete RCTs, met the inclusion criteria (see Figure 1). 
Figure 1. Preferred Reporting Items for Systematic Reviews and Meta-Analyses (PRISMA) flow diagram summarizing the process of selecting eligible studies for the systematic review. RCT: randomized controlled trial, T2DM: type 2 diabetes.

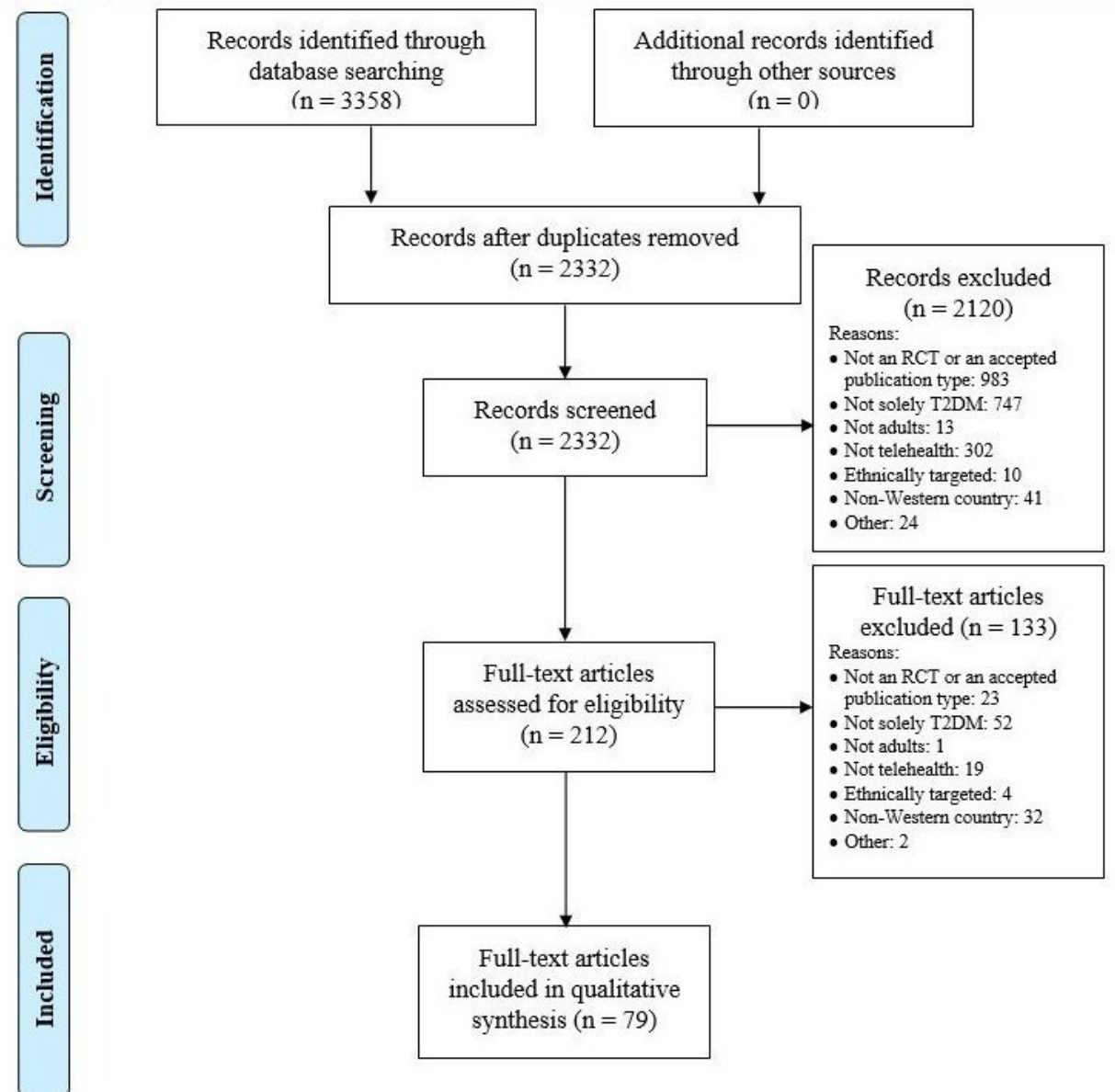

\section{Characteristics of Included Studies}

Multimedia Appendix 2 summarizes the characteristics of included studies in the review. The total number of participants across included RCTs was 12,916, with sample sizes ranging from 14 to 1665 (median 160). Nearly three-quarters (43/58) were recruited from the United States, whereas the rest were carried out in Australia (5/58), Canada (5/58), the United Kingdom (4/58), and one in both the United States and Canada. The studies involved a wide range of telehealth media and devices, the most popular of which was phone-based telehealth interventions. Other frequently used telehealth tools included Internet technologies (eg, static and interactive webpages, email, instant messaging), computerized self-management programs, and glucose meters integrated with mobile apps. Several studies combined different media and communication types as part of the intervention, including electronic medical records, educational websites, home monitoring, and videoconferencing (eg, [66]).

\section{Methodological Quality}

Parts A and B of Multimedia Appendix 3 show the ROB summary table and graph for included studies. Of the 79 articles, 34 described an appropriate randomization procedure, two $[67,68]$ reported inadequate randomization, and the remainder provided insufficient detail for assessing risk of selection bias (judged unclear). Similarly, allocation concealment reporting was frequently insufficient to determine the ROB (eg, not clear whether allocation envelopes were opaque and sequentially numbered [69]). Most studies reported designs intended to reduce performance bias (within the parameters of unfeasible patient and interventionist blinding), with studies judged as having a high ROB in cases when nonblinded staff delivered both the telehealth intervention and usual care [69-83] and also collected follow-up measures [84,85]. Included studies employed both subjective and objective outcome measures, with objective glycated hemoglobin $\left(\mathrm{HbA}_{1 \mathrm{c}}\right)$ levels being the most common primary outcome. Approximately half of the studies included patient attrition information, with unclear ROB assigned when reasons for attrition were not given, attrition was not broken down by group allocation, or it was unclear how substantial missing data were dealt with in data analysis. Several studies were assessed as having a high ROB due to a large difference in attrition between study arms that was attributed to the intervention $[86,87]$ or that had only presented outcomes for patients who had completed the intervention and/or all follow-up measures [88-91]. There was generally a low risk of reporting bias, with most studies reporting on prespecified outcomes. A high ROB was noted in studies where reported outcomes deviated from the protocol or specified methodologies [70,85,91-97] or insufficiently reported statistical or summary data $[67,68,71,72,83,98-105]$. Most studies were free of other sources of bias. However, some failed to report treatment dosage (eg, frequency of calls $[74,90,106,107])$ and its effect on 
outcomes even when adherence was low. Others were pilot studies or had small convenience samples, limiting their generalizability [71,85,95,101,108,109].

\section{Ethnic Minority Participation}

Thirty-eight of the 58 included RCTs (or 56 of the 79 articles) provided information on the ethnic composition of the sample [66-78,80,85,87,89,91-98,100-130], of which the median proportion of ethnic minority participants was $23.5 \%$ (range
0\%-97.7\%). Two of these recruited no ethnic minority patients $[71,77]$. The remaining studies $(n=20)$ provided no ethnicity information, including all five Canadian studies [79,81-84,86,88,90,99,131-144]. Figure 2 shows that the number of included studies in the review markedly increased after 2005, with eight up until that year and 50 thereafter. The proportion of the studies that reported on the ethnicity of recruited patients was 38\% (3/8) up to and including 2005 and more than doubled to $70 \%(35 / 50)$ after that date.

Figure 2. Number of included studies $(n=58)$ reporting on the ethnic composition of the recruited sample by year of publication.

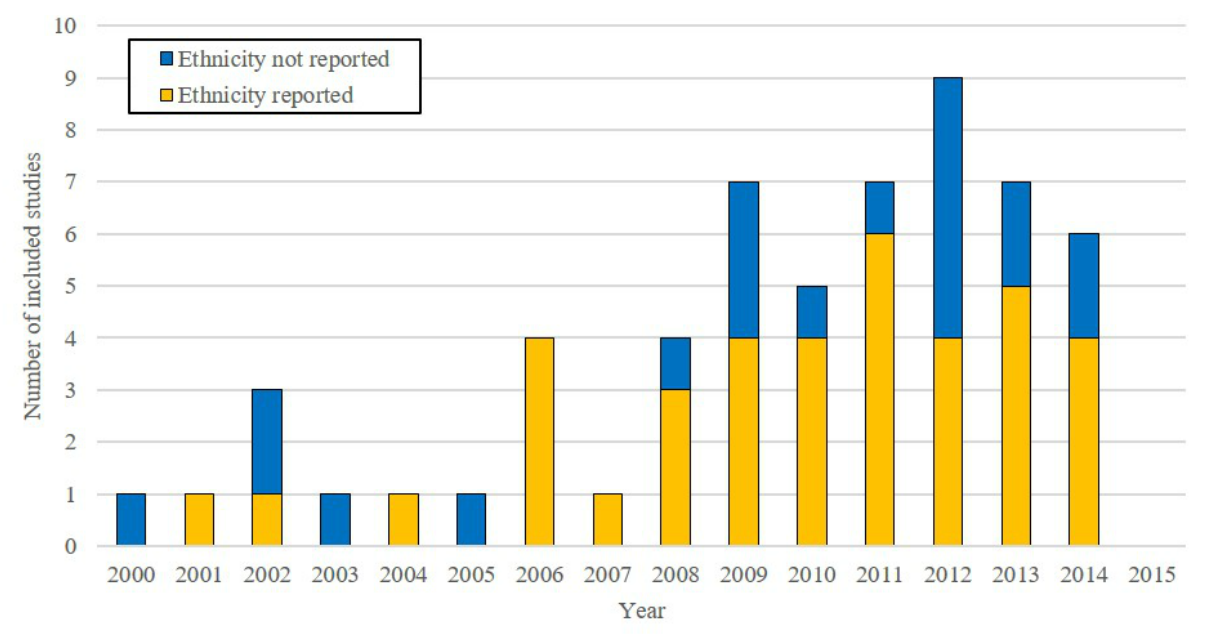

\section{Language Proficiency}

Half of the included RCTs (29/58) reported English language proficiency as a patient inclusion or exclusion criterion, with six of these studies alternatively requiring proficiency in Spanish $[66,94,105,106,110,111]$ and one in either Spanish or Cantonese instead of English [118]. In the 29 remaining RCTs, language ability may have been considered in recruitment but not reported in the published article, including one study that did not list any screening criteria at all [72]. Alternatively, language might not have been taken into account in recruitment. Although being able to engage with the intervention may be an implicit reason for including language as an eligibility criterion, only three studies provided explicit explanations for excluding prospective participants on language grounds. In two, this pertained to understanding study information and providing informed consent $[99,109]$. In the third, this related to language demands required for the intervention, which involved patients receiving tailored feedback through an automated interactive phone service [142].

Of the studies that included language proficiency as an eligibility criterion, there was little consistency in the way that this was defined. More than a third (11/29) emphasized being able to communicate in or fluently speak (and in two cases also understand) English, whereas another specified language without reference to the written medium. Of these, two studies further specified that the context for this was over the phone [91,142], which is more difficult than face-to-face communication [42]. Four other studies referred to participants needing to be able to read and speak English, seven required reading and writing, and two referred to reading and understanding (ie, receptive skills), placing no apparent emphasis on speaking or writing. Finally, five studies emphasized having English (or Spanish) as a main or primary language, implying that membership to the target language community (ie, native speaker status) was the key criterion.

From these descriptions, there were no indications that any objective measures (eg, temporal measures of fluency or oral comprehension questions) were used to establish whether prospective participants had the necessary skills to meet the specified language criterion for inclusion in the study. Reference to commonly used benchmarks of language proficiency or defined levels (eg, Canadian Language Benchmarks, Common European Framework of Reference for Languages) were not given [145]. The grounds on which a patient was determined to be linguistically eligible to participate were also unspecified. Two studies administered previously validated health literacy instruments to patients $[75,118]$. However, this was used to assess study outcomes in relation to health literacy and there was no threshold health literacy level required for participation. In sum, there were no explicit or standardized measures of language proficiency across included studies — a variable which could directly affect the ethnic minority patient participation [146].

\section{Narrative Synthesis}

Of the 79 articles reporting on 14 distinct RCTs, 28 recruited a high proportion of ethnic minority patients, with the threshold for this set at $30 \%$ or greater (median 53.3\%, range $30.0 \%-97.7 \%$; see Table 1) $[66,70,75,85,87,94,103,105,106$, $110,111,116,118,119]$. They all took place in the United States, mostly in urban settings, with only one study exclusively recruiting from a rural setting [70]. These studies frequently recruited in medically underserved and financially deprived areas $[66,70,106,110,111]$ and described their target populations 
as predominantly uninsured $[75,106,111,118]$. In addition to including ethnic minorities, these studies also had high numbers of patients with no insurance or who received government-sponsored Medicare or Medicaid benefits. For example, of the three studies recruiting patients from safety-net clinics, which treat uninsured patients, more than $89 \%$ were nonwhite [75,110,118]. Two studies required health care coverage as a patient screening criterion $[87,103]$ and one solely recruited low paid health care worker union members insured through their employer [105].

Table 1. Summary of characteristics of 14 parent studies with a high proportion $(\geq 30 \%)$ of ethnic minority patients.

\begin{tabular}{|c|c|c|c|c|c|c|c|c|c|}
\hline \multirow[t]{2}{*}{ Study } & \multirow{2}{*}{$\begin{array}{l}\text { Intervention } \\
\text { Telehealth medium }\end{array}$} & \multicolumn{3}{|c|}{ Setting and patient characteristics ${ }^{\mathrm{a}}$} & \multicolumn{2}{|c|}{$\begin{array}{l}\text { Benefits of participa- } \\
\text { tion }^{b}\end{array}$} & \multicolumn{3}{|c|}{ Tailoring of intervention ${ }^{\mathrm{c}}$} \\
\hline & & $\begin{array}{l}\text { Recruit- } \\
\text { ment }\end{array}$ & Urban only & Underserved & Financial & Device & Bilingual & Cultural & Literacy \\
\hline $\begin{array}{l}\text { Anderson et al } \\
{[106]}\end{array}$ & Phone & $\mathrm{PC}$ & Yes & Yes & Yes & & Yes & & Yes \\
\hline Arora et al [110] & Mobile SMS & $\mathrm{SN}$ & Yes & Yes & Yes & & Yes & Yes & Yes \\
\hline Davis et al [70] & $\begin{array}{l}\text { Videoconference \& } \\
\text { pedometer }\end{array}$ & $\mathrm{PC}$ & Rural & Yes & Yes & & & Yes & Yes \\
\hline Frosch et al [111] & Video \& phone & PC Com & Yes & Yes & & & Yes & & \\
\hline $\begin{array}{l}\text { Glasgow et al } \\
\text { [94] }\end{array}$ & $\begin{array}{l}\text { Website \& phone (au- } \\
\text { tomated \& from an in- } \\
\text { terventionist) }\end{array}$ & $\mathrm{PC}$ & Yes & & & & Yes & Yes & \\
\hline Khan et al [75] & $\begin{array}{l}\text { Computer multimedia } \\
\text { education }\end{array}$ & SN & Yes & Yes & & & Yes & Yes & Yes \\
\hline Krein et al [116] & Phone & $\mathrm{PC}$ & Yes & & & & & & \\
\hline Quinn et al [85] & $\begin{array}{l}\text { Bluetooth blood glu- } \\
\text { cose meter with mo- } \\
\text { bile app }\end{array}$ & PC Com & Mixed & & & Yes & & & \\
\hline Quinn et al [87] & $\begin{array}{l}\text { Mobile SMS, patient } \\
\text { portal \& phone }\end{array}$ & $\mathrm{PC}$ & Mixed & & & Yes & & & \\
\hline $\begin{array}{l}\text { Schillinger et al } \\
\text { [118] }\end{array}$ & Phone & $\mathrm{SN}$ & Yes & Yes & Yes & & Yes & & Yes \\
\hline Sevick et al [119] & $\begin{array}{l}\text { Personal digital assis- } \\
\text { tant }\end{array}$ & Com & Yes & & Yes & Yes & & & \\
\hline Shea et al [66] & $\begin{array}{l}\text { Website, videoconfer- } \\
\text { ence, electronic } \\
\text { records \& email }\end{array}$ & $\mathrm{PC}$ & Mixed & Yes & & Yes & Yes & & Yes \\
\hline Tang et al [103] & $\begin{array}{l}\text { Bluetooth blood glu- } \\
\text { cose meter \& electron- } \\
\text { ic records }\end{array}$ & $\mathrm{PC}$ & Yes & & & Yes & & & \\
\hline $\begin{array}{l}\text { Walker et al } \\
{[105]}\end{array}$ & Phone & Union & Yes & Yes & & & Yes & & \\
\hline
\end{tabular}

\footnotetext{
${ }^{a}$ Recruitment: Description of setting from which participants were recruited; PC: primary care; SN: safety net; Com: community center; Union: health care workers' union. Urban only: refers to recruitment solely from urban areas. All mixed studies recruited from both urban and rural areas, with the exception of [85], which recruited from urban and suburban areas. Underserved: medically underserved/uninsured/low-wage patients or Medicare/Medicaid beneficiaries.

${ }^{\mathrm{b}}$ Financial: monetary incentives for research participation, including money, gift cards, or vouchers. Device: provision of technology or equipment including self-monitoring devices used in the intervention.

${ }^{\mathrm{c}}$ Bilingual: recruitment or educational materials translated into a minority language or availability of bilingual interventionists. Cultural: materials crafted for or through consultation with members from certain minority communities independent of language. Literacy: materials purposefully written at a particular grade level or staff trained to communicate with low-literacy patients.
}

High minority-recruiting studies used a mix of telehealth for trial participation, with money or vouchers ranging from delivery modes, reflecting the breadth of technology used in US \$15 to US \$175 per participant [70,106,110,118,119]. By the wider sample of studies included in the review. This suggests comparison, only $21 \%(5 / 24)$ of low-recruiting studies $(<30 \%$ that the medium through which a telehealth intervention is ethnic minorities) offered financial incentives. A proportionately delivered has little bearing on ethnic minority recruitment. In higher number of high minority-recruiting trials (35.7\% vs $21 \%$ total, $36 \%(5 / 14)$ of the studies offered financial compensation in low-recruiting studies) also offered patients equipment to 
facilitate self-monitoring, such as glucose meters and/or blood testing strips, which can impose a substantial cost to patients not covered by insurance [70,106,110,118,119], or free mobile phones if they were being used as part of the intervention $[85,87,103]$.

Another key characteristic of high minority-recruiting studies was an emphasis on languages other than English. More than half $(8 / 14)$ offered the intervention in a language other than English, including the use of bilingual staff for phone interventions $[66,75,94,105,106,110,111,118]$, and two additionally reported using bilingual recruitment staff or translated study information to facilitate the recruitment of nonnative-English-speaking patients [94,118]. Conversely, no study with less than $30 \%$ ethnic minority participants offered bilingual interventions (see Multimedia Appendix 2). Four studies reported tailoring intervention materials to the needs and interests of African American and/or Latino patients, such as the use of video testimonials from community members $[70,75,94,110]$, and nearly half reported writing study materials to facilitate low-literacy patients' comprehension [66,70,75,106,110,118].

\section{Post Hoc Subgroup Analysis}

A post hoc subgroup analysis was conducted for 12 articles comprising 11 RCTs that had been excluded during full-text screening [54-65]. The findings echoed those of the narrative synthesis (see Table 2). All ethnically targeted studies took place in urban American settings, with nearly half (5/11) reportedly recruiting from economically deprived or medically underserved areas $[56,57,60,61,65]$. More than half $(6 / 11)$ used phone calls as part of the intervention, although other telehealth media were also used. Although only one study offered patients intervention-related equipment (laptop and telehealth peripherals) [57], six offered financial remuneration ranging from US $\$ 40$ to US $\$ 60$ cash or vouchers [55,59,61-63,65], with one trial additionally offering some patients up to US $\$ 200$ for reducing their $\mathrm{HbA}_{1 \mathrm{c}}$ levels by a prespecified amount [62]. The ethnically targeted studies frequently reported tailoring interventions to their target demographic, including offering written and spoken aspects of the intervention in a language other than English [56,61,64,65], designing interventions through consultation and feedback from minority groups [55-58,60,65], and using interventionists drawn from the target cultural communities $[55,61,64,65]$. This latter point included building input from minorities into the recruitment strategy and/or piloting materials and procedures with them. 
Table 2. Summary of characteristics of 11 ethnically targeted studies subjected to a post hoc subgroup analysis.

\begin{tabular}{|c|c|c|c|c|c|c|c|c|}
\hline \multirow[t]{2}{*}{ Study } & \multirow{2}{*}{$\begin{array}{l}\text { Intervention } \\
\text { Telehealth medium }\end{array}$} & \multicolumn{3}{|c|}{ Setting and patient characteristics ${ }^{\mathrm{a}}$} & \multicolumn{2}{|c|}{ Incentives $^{\mathrm{b}}$} & \multicolumn{2}{|c|}{ Tailoring of intervention } \\
\hline & & $\begin{array}{l}\text { Recruit- } \\
\text { ment }\end{array}$ & Recruited group(s) & Underserved & Financial & Bilingual & Cultural & Literacy \\
\hline $\begin{array}{l}\text { Amoako \& } \\
\text { Skelly [55] }\end{array}$ & Phone & PC com & $\begin{array}{l}\text { Older African } \\
\text { American women }\end{array}$ & & Yes & & Yes & Yes \\
\hline $\begin{array}{l}\text { Calderón et al } \\
{[56]}\end{array}$ & Video & $\mathrm{PC}$ & Spanish speakers & Yes & & Yes & Yes & Yes \\
\hline Carter et al [57] & $\begin{array}{l}\text { Laptop with home } \\
\text { monitoring, videocon- } \\
\text { ference \& electronic } \\
\text { records }\end{array}$ & $\mathrm{PC}$ & African Americans & Yes & & & Yes & \\
\hline $\begin{array}{l}\text { Crowley et al } \\
{[58]}\end{array}$ & Phone & $\mathrm{PC}$ & African Americans & & & & Yes & Yes \\
\hline $\begin{array}{l}\text { Forjuoh et al } \\
{[59] ; \text { Adepoju }} \\
\text { et al }[54]^{d}\end{array}$ & $\begin{array}{l}\text { Personal digital assis- } \\
\text { tant }\end{array}$ & $\mathrm{PC}$ & $\begin{array}{l}\text { African Americans } \\
\text { \& Hispanics }\end{array}$ & & Yes & & & \\
\hline Gary et al [60] & Phone & $\mathrm{PC}$ & African Americans & Yes & & & Yes & \\
\hline $\begin{array}{l}\text { Heisler et al } \\
{[61]}\end{array}$ & Tablet computer & Com & $\begin{array}{l}\text { African Americans } \\
\text { \& Hispanics }\end{array}$ & Yes & Yes & Yes & Yes & Yes \\
\hline Long et al [62] & Phone & $\mathrm{PC}$ & $\begin{array}{l}\text { African American } \\
\text { veterans }\end{array}$ & & Yes & & & \\
\hline Lorig et al [64] & Phone & Com & Spanish speakers & & & Yes & Yes & \\
\hline Lorig et al [63] & Website & Web & $\begin{array}{l}\text { American Indians/ } \\
\text { Alaska Natives }\end{array}$ & & Yes & & & \\
\hline $\begin{array}{l}\text { Ruggiero et al } \\
{[65]}\end{array}$ & Phone & $\mathrm{PC}$ & $\begin{array}{l}\text { African Americans } \\
\& \text { Hispanics }\end{array}$ & Yes & Yes & Yes & Yes & Yes \\
\hline
\end{tabular}

${ }^{a}$ Recruitment: Description of setting from which participants were recruited; PC: primary care; com: community center; Web: website. Recruited group(s): ethnicities targeted in recruitment and age group, gender, or profession of targeted participants where specified. Underserved: medically underserved/uninsured/low-wage patients or Medicare/Medicaid beneficiaries.

${ }^{\mathrm{b}}$ Financial: monetary incentives for research participation, including money or vouchers. Bilingual: recruitment or educational materials translated into a minority language or availability of bilingual interventionists.

${ }^{\mathrm{c}}$ Cultural: materials crafted for or through consultation with members from certain minority communities independent of language, or staff undertook cultural sensitivity training. Literacy: materials purposefully written at a particular grade level or staff trained to communicate with low-literacy patients.

$\mathrm{d}$ These linked articles reported on the same RCT and it was unclear which was the parent study.

\section{Discussion}

\section{Principal Findings}

This systematic review investigated research reporting practices and prevalence estimates of ethnic minority participation in telehealth diabetes RCTs, extending previous reviews by including a broader range of telehealth technologies targeting type 2 diabetes. Nearly $66 \%$ of included studies reported on the ethnic composition of their samples. Although this proportion is higher than in previous reviews $[3,33,34]$, it confirms the underreporting of ethnicity in peer-reviewed journal articles. However, compared to the 2006 review that had also excluded studies recruiting participants from a single ethnic minority background [33], these results yielded lower median participation of ethnic minority patients as a proportion of the total sample $(23.5 \%$ vs $39 \%)$.

All RCTs with $30 \%$ or greater ethnic minority recruitment were US-based, mostly recruited from urban areas, and frequently described recruited patients as low-income, socially deprived, or with little or no health care coverage. Participant remuneration or free telehealth monitoring devices incentivized participation in nearly $60 \%$ of these studies. Although the United States has a high proportion of ethnic minorities compared to other countries included in the review [147], its dominance as the setting for all studies meeting the $30 \%$ or greater cut-off for the narrative review and for all ethnically targeted studies in the post hoc subgroup analysis suggests that the American National Institutes of Health (NIH) Policy and Guidelines on the Inclusion of Women and Minorities as Subjects in Clinical Research [148] has been influential in promoting minority representation in trials. Overall, minority participation rates tend to be higher in the United States, which has legislation to mandate their inclusion, than in contexts where no such legislation exists (eg, United Kingdom) [26]. The availability of trial materials in multiple languages was also a recurrent feature of studies recruiting substantial numbers of ethnic minority participants and often occurred in conjunction with trial materials that accounted for cultural factors or presumed literacy levels. This suggests that having a language concordant 
interventionist and embedding input from members of target communities into trial materials could have positive effects on the recruitment of groups who may otherwise be underrepresented $[149,150]$. This supports existing research on strategies to optimize the recruitment of underserved patients, which reveals ways of working holistically to alleviate individual and external factors that impede participation $[146,151]$. The emphasis on patient and public involvement in research aligns with such practices $[29,152]$.

Half of the included studies listed language proficiency among the patient eligibility criteria, although less than $5 \%$ provided a reason for including or excluding patients on this basis. The role of language in participant screening was described in different ways across studies, with emphasis either placed on different combinations of skills (speaking, listening, reading, writing) to reflect the nature of the intervention, or on patients' status as primary speakers of English or another language where offered. There was no evidence of the use of objective measures or instruments or of a common procedure across studies to assess whether patients had the requisite language proficiency to participate and, in individual studies, this level of detail was not given. Thus, it was unclear how language-related determinations about inclusion or exclusion were made- that is, how the language-screening criterion as stated was operationalized in arriving at eligibility decisions.

\section{Limitations}

This review has several limitations. First, only English-language articles that recruited patients from Western countries where English is both an official and the dominant language were considered. Findings may be different in reviews focusing on recruitment from other contexts or on other world languages. Second, ethnic minorities are not a monolith, and language barriers to engaging with the intervention are likely to be different for newcomers to a country (eg, migrants), who may have little knowledge of English, than for later generations of native English speakers who are visible minorities (eg, African Americans in the United States) [24]. It is often difficult to disentangle ethnicity from language in secondary data analysis because the language background of participants (ie, proportion of native English speakers and heritage language speakers) is often not reported as a separate category and, in some countries, is not captured in census data [40]. Third, and related to this, we used the ethnicity categories reported in the original studies in data extraction. However, race and ethnicity are complex constructs that frequently conflate social identity with other factors, such as genetic or biological characteristics (particularly as connoted in the former term), geographical origin, cultural practices, or religious persuasion [31]. Categorizations were inconsistent across studies included in this review, making comparisons between and within countries difficult. Fourth, the prevalence of minority patients in the area(s) from which they were recruited was not possible to collate, with several studies recruiting from different geographic sites and not reporting on local population or, in some cases, on the ethnic breakdown of their recruited sample. Finally, peer-reviewed articles were the sole publication type considered in this study, which was consistent with the goal of elucidating research reporting practices in academic journals. That is, the grey literature was not examined and study authors were not contacted to provide further information than was included in their published articles, taking into account linked publications. The brief descriptions of study setting, design, and recruitment in the included telehealth RCTs provided comparatively little qualitative data for the narrative synthesis. This has resulted in a relatively simple theoretical account of the trial features supporting ethnic minority participation, which would need to be corroborated through a more in-depth examination of key variables in subsequent research. Nonetheless, with 79 articles and 58 RCTs included, this review is comprehensive in its account of research reporting and includes more studies than the three previous telehealth diabetes reviews combined [3,33,34].

\section{Concluding Remarks}

Despite the link between new technologies and improved outcomes, mixed evidence regarding reducing disparities from the research literature [122,129] suggests that telehealth has yet to fulfill its potential of being truly accessible to and effective for ethnic minority diabetes patients [15]. Cultural and linguistic tailoring to a diverse demographic and offering translation and interpretation services where possible could extend the benefits of telehealth type 2 diabetes interventions to a wider cross-section of patients, thereby promoting more equitable access to health care $[43,153]$.

Findings from this and earlier systematic reviews suggest that between a third and half of telehealth diabetes trials provide no information on the ethnic composition of their samples. Further, other demographic characteristics, such as socioeconomic status, are not consistently reported across studies (see Multimedia Appendix 2). Providing data on participants' gender and age, but no information on ethnicity for either the sample or the local target population is insufficient for assessing the external validity of the findings. Ethnicity information is necessary to evaluate claims about telehealth's accessibility to all patients (and not just a subsection of the population), including its ability to foster social inclusion through the uptake of services.

The Consolidated Standards of Reporting Trials (CONSORT) statement [154], which articulates guidelines for best practice in research reporting and which has been widely adopted, advocates reporting baseline demographic and clinical characteristics for each group in the RCT. However, this is prefaced on the assumption that these will be collected, and the statement does not specify which baseline variables should be captured and described. In the case of clinical baseline variables, further specification of which variables to target would appear to be dependent on the nature of the condition being examined (eg, $\mathrm{HbA}_{1 \mathrm{c}}$ for diabetes). However, this is not the case for sociodemographic variables, which apply regardless of the disease type being investigated. In trials targeting chronic conditions in which prevalence is known to vary by ethnicity and other social factors, further specification of the baseline demographic characteristics that should be reported on could reduce the variability in between-study reporting. This would assist in examining crucial relationships between sociodemographic variables and health outcomes. Journal editors and editorial boards could converge on the most important sociodemographic characteristics that should be reported (eg, 
in a checklist) to achieve greater consistency and help streamline such information across studies.

Finally, the fact that telehealth trials seek to recruit patients with an adequate level of language ability is understandabletelehealth interventions rely on effective spoken or written communication as a key part of the "treatment." However, the absence of an objective or standardized measure for assessing whether patients have the requisite language ability to successfully engage with the intervention suggests that such decisions are likely being made on the basis of trial recruiters' subjective judgments. This creates a risk of selection bias, as trial recruiters might exclude ethnic minority participants based on the subjective view that they will not be able to adequately take part in the intervention, despite actually having sufficient language proficiency [43]. For example, recruiters may misjudge having a perceptible foreign accent as evidence of poor language ability in instances when this does not actually impede communication $[155,156]$. Conversely, including patients who do not understand the nature of the intervention due to language barriers is problematic, not least for ethical reasons [157]. Future research could focus on the development and validation of a tool to provide trial recruiters with a simple, practical means of assessing language proficiency for trial participation to minimize the possibility of patients being unfairly excluded based on arbitrary judgments.

\section{Acknowledgments}

This project was partially funded by a European Commission FP7 Marie Curie Grant awarded to TI (PCIG10-GA-2011-30341 3) and dissemination was supported by OpenAIRE FP7 Post-Grant Open Access Pilot. The investigation was also supported by the Medical Research Council (MRC) Collaboration and Innovation for Difficult Trials in Invasive procedures (ConDuCT-II) Hub for Trials Methodology Research (MR/K025643/1). We are grateful to Rebecca Barnes, Karen Bell (KB), Jane M Blazeby, Catherine Borwick, Sean Cowlishaw, Padraig Dixon, Jenny L Donovan, Julian Higgins, Alyson Huntley, Gwerfyl Roberts, Waquas Waheed, Bridget Young, and JMIR ResProtoc anonymous reviewers for their input on the protocol or an earlier related proposal.

\section{Authors' Contributions}

The study was initially conceptualized by TI and LE; carried out by LE, DH, DW, and KB (abstract and full-text screening, ROB assessment, data extraction); with the review jointly drafted by TI and DH, drawing on the published protocol. All authors contributed to and approved this manuscript.

\section{Conflicts of Interest}

None declared.

\section{Multimedia Appendix 1}

Data extraction form.

[PDF File (Adobe PDF File), 35KB-Multimedia Appendix 1]

\section{Multimedia Appendix 2}

Summary of included studies in the review.

[PDF File (Adobe PDF File), 67KB-Multimedia Appendix 2]

\section{Multimedia Appendix 3}

A. Risk of bias assessment summary. B. Risk of bias assessment graph.

[PDF File (Adobe PDF File), 104KB-Multimedia Appendix 3]

\section{References}

1. World Health Organization. Global Report on Diabetes. Geneva: World Health Organization; 2016. URL: http://apps. who.int/iris/bitstream/10665/204871/1/9789241565257 eng.pdf [accessed 2016-09-11] [WebCite Cache ID 6kREZjPza]

2. Diabetes UK. Facts and Stats 2015. 2015 Nov. URL: https://www.diabetes.org.uk/Documents/Position\%20statements/ Diabetes\%20UK\%20Facts\%20and\%20Stats Dec\%202015.pdf [accessed 2016-04-08] [WebCite Cache ID 6gcHW2TBL]

3. Cotter AP, Durant N, Agne AA, Cherrington AL. Internet interventions to support lifestyle modification for diabetes management: a systematic review of the evidence. J Diabetes Complications 2014;28(2):243-251 [FREE Full text] [doi: 10.1016/j.jdiacomp.2013.07.003] [Medline: 24332469]

4. Institute of Medicine Committee on Evaluating Clinical Applications of Telemedicine. In: Field MJ, editor. Telemedicine: A Guide to Assessing Telecommunications in Health Care. Washington, DC: National Academies Press; 1996. 
5. Edwards L, Thomas C, Gregory A, Yardley L, O'Cathain A, Montgomery AA, et al. Are people with chronic diseases interested in using telehealth? A cross-sectional postal survey. J Med Internet Res 2014;16(5):e123 [FREE Full text] [doi: 10.2196/jmir.3257] [Medline: 24811914]

6. Ackerman MJ, Filart R, Burgess LP, Lee I, Poropatich RK. Developing next-generation telehealth tools and technologies: patients, systems, and data perspectives. Telemed J E Health 2010;16(1):93-95 [FREE Full text] [doi: 10.1089/tmj.2009.0153] [Medline: 20043711]

7. Greenwood DA, Hankins AI, Parise CA, Spier V, Olveda J, Buss KA. A comparison of in-person, telephone, and secure messaging for type 2 diabetes self-management support. Diabetes Educ 2014 Apr 17;40(4):516-525. [doi: 10.1177/0145721714531337] [Medline: 24742540]

8. Bashshur RL, Shannon GW, Smith BR, Woodward MA. The empirical evidence for the telemedicine intervention in diabetes management. Telemed J E Health 2015 May;21(5):321-354 [FREE Full text] [doi: 10.1089/tmj.2015.0029] [Medline: 25806910]

9. Polisena J, Tran K, Cimon K, Hutton B, McGill S, Palmer K. Home telehealth for diabetes management: a systematic review and meta-analysis. Diabetes Obes Metab 2009 Oct;11(10):913-930. [doi: 10.1111/j.1463-1326.2009.01057.x] [Medline: 19531058 ]

10. Worswick J, Wayne SC, Bennett R, Fiander M, Mayhew A, Weir MC, et al. Improving quality of care for persons with diabetes: an overview of systematic reviews - what does the evidence tell us? Syst Rev 2013;2:26 [FREE Full text] [doi: 10.1186/2046-4053-2-26] [Medline: 23647654]

11. Toma T, Athanasiou T, Harling L, Darzi A, Ashrafian H. Online social networking services in the management of patients with diabetes mellitus: systematic review and meta-analysis of randomised controlled trials. Diabetes Res Clin Pract 2014 Nov;106(2):200-211. [doi: 10.1016/j.diabres.2014.06.008] [Medline: 25043399]

12. Riazi H, Larijani B, Langarizadeh M, Shahmoradi L. Managing diabetes mellitus using information technology: a systematic review. J Diabetes Metab Disord 2015;14:49 [FREE Full text] [doi: 10.1186/s40200-015-0174-x] [Medline: 26075190]

13. Wilson C, Alam R, Latif S, Knighting K, Williamson S, Beaver K. Patient access to healthcare services and optimisation of self-management for ethnic minority populations living with diabetes: a systematic review. Health Soc Care Community 2012 Jan;20(1):1-19. [doi: 10.1111/j.1365-2524.2011.01017.x] [Medline: 21749529]

14. Long AF, Gambling T, Young RJ, Taylor J, Mason JM. Acceptability and satisfaction with a telecarer approach to the management of type 2 diabetes. Diabetes Care 2005 Feb;28(2):283-289. [Medline: 15677780]

15. Zhai Y, Zhu W, Cai Y, Sun D, Zhao J. Clinical- and cost-effectiveness of telemedicine in type 2 diabetes mellitus: a systematic review and meta-analysis. Medicine (Baltimore) 2014 Dec;93(28):e312 [FREE Full text] [doi: 10.1097/MD.0000000000000312] [Medline: 25526482]

16. Amante DJ, Hogan TP, Pagoto SL, English TM, Lapane KL. Access to care and use of the Internet to search for health information: results from the US National Health Interview Survey. J Med Internet Res 2015;17(4):e106 [FREE Full text] [doi: 10.2196/jmir.4126] [Medline: 25925943]

17. Gibbons MC. A historical overview of health disparities and the potential of eHealth solutions. J Med Internet Res 2005;7(5):e50 [FREE Full text] [doi: 10.2196/jmir.7.5.e50] [Medline: 16403714]

18. Khunti K, Morris DH, Weston CL, Gray LJ, Webb DR, Davies MJ. Joint prevalence of diabetes, impaired glucose regulation, cardiovascular disease risk and chronic kidney disease in South Asians and White Europeans. PLoS One 2013;8(1):e55580 [FREE Full text] [doi: 10.1371/journal.pone.0055580] [Medline: 23383233]

19. Negandhi PH, Ghouri N, Colhoun HM, Fischbacher CM, Lindsay RS, McKnight JA, Scottish Diabetes Research Network Epidemiology Group. Ethnic differences in glycaemic control in people with type 2 diabetes mellitus living in Scotland. PLoS One 2013;8(12):e83292 [FREE Full text] [doi: 10.1371/journal.pone.0083292] [Medline: 24358273]

20. Nazroo J. The Health of Britain's Ethnic Minorities: Findings from a National Survey. London: Policy Studies Institute; 1997.

21. Sinha SK, Shaheen M, Rajavashisth TB, Pan D, Norris KC, Nicholas SB. Association of race/ethnicity, inflammation, and albuminuria in patients with diabetes and early chronic kidney disease. Diabetes Care 2014 Apr;37(4):1060-1068 [FREE Full text] [doi: 10.2337/dc13-0013] [Medline: 24550221]

22. Rawshani A, Svensson AM, Rosengren A, Zethelius B, Eliasson B, Gudbjörnsdottir S. Impact of ethnicity on progress of glycaemic control in 131,935 newly diagnosed patients with type 2 diabetes: a nationwide observational study from the Swedish National Diabetes Register. BMJ Open 2015;5(6):e007599 [FREE Full text] [doi: 10.1136/bmjopen-2015-007599] [Medline: 26048210]

23. Abouzeid M, Philpot B, Janus ED, Coates MJ, Dunbar JA. Type 2 diabetes prevalence varies by socio-economic status within and between migrant groups: analysis and implications for Australia. BMC Public Health 2013;13:252 [FREE Full text] [doi: 10.1186/1471-2458-13-252] [Medline: 23517376]

24. Majeed-Ariss R, Jackson C, Knapp P, Cheater FM. A systematic review of research into black and ethnic minority patients' views on self-management of type 2 diabetes. Health Expect 2015 Oct;18(5):625-642. [doi: 10.1111/hex.12080] [Medline: 23710892]

25. Szczepura A. Access to health care for ethnic minority populations. Postgrad Med J 2005 Mar;81(953):141-147 [FREE Full text] [doi: 10.1136/pgmj.2004.026237] [Medline: $\underline{\text { 15749788] }}$ 
26. Brown G, Marshall M, Bower P, Woodham A, Waheed W. Barriers to recruiting ethnic minorities to mental health research: a systematic review. Int J Methods Psychiatr Res 2014 Mar;23(1):36-48. [doi: 10.1002/mpr.1434] [Medline: 24474683]

27. Newlin K, Melkus GD, Jefferson V, Langerman S, Womack J, Chyun D. Recruitment of black women with type 2 diabetes into a self-management intervention trial. Ethn Dis 2006;16(4):956-962. [Medline: 17061753]

28. Ford JG, Howerton MW, Lai GY, Gary TL, Bolen S, Gibbons MC, et al. Barriers to recruiting underrepresented populations to cancer clinical trials: a systematic review. Cancer 2008 Jan 15;112(2):228-242 [FREE Full text] [doi: 10.1002/cncr.23157] [Medline: 18008363 ]

29. Bonevski B, Randell M, Paul C, Chapman K, Twyman L, Bryant J, et al. Reaching the hard-to-reach: a systematic review of strategies for improving health and medical research with socially disadvantaged groups. BMC Med Res Methodol 2014;14:42 [FREE Full text] [doi: 10.1186/1471-2288-14-42] [Medline: 24669751]

30. Meuter RF, Gallois C, Segalowitz NS, Ryder AG, Hocking J. Overcoming language barriers in healthcare: A protocol for investigating safe and effective communication when patients or clinicians use a second language. BMC Health Serv Res 2015;15:371 [FREE Full text] [doi: 10.1186/s12913-015-1024-8] [Medline: 26357948]

31. Bartlett C, Doyal L, Ebrahim S, Davey P, Bachmann M, Egger M, et al. The causes and effects of socio-demographic exclusions from clinical trials. Health Technol Assess 2005 Oct;9(38):iii-iv, ix [FREE Full text] [Medline: 16181564]

32. Foster A, Horspool KA, Edwards L, Thomas CL, Salisbury C, Montgomery AA, et al. Who does not participate in telehealth trials and why? A cross-sectional survey. Trials 2015;16:258 [FREE Full text] [doi: 10.1186/s13063-015-0773-3] [Medline: $\underline{26044763}$ ]

33. Jackson CL, Bolen S, Brancati FL, Batts-Turner ML, Gary TL. A systematic review of interactive computer-assisted technology in diabetes care. Interactive information technology in diabetes care. J Gen Intern Med 2006 Feb;21(2):105-110 [FREE Full text] [doi: 10.1111/j.1525-1497.2005.00310.x] [Medline: 16390512]

34. Pal K, Eastwood SV, Michie S, Farmer A, Barnard ML, Peacock R, et al. Computer-based interventions to improve self-management in adults with type 2 diabetes: a systematic review and meta-analysis. Diabetes Care 2014 Jun;37(6):1759-1766. [doi: 10.2337/dc13-1386] [Medline: 24855158]

35. Wanner M, Martin-Diener E, Bauer G, Braun-Fahrländer C, Martin BW. Comparison of trial participants and open access users of a web-based physical activity intervention regarding adherence, attrition, and repeated participation. J Med Internet Res 2010;12(1):e3 [FREE Full text] [doi: 10.2196/jmir.1361] [Medline: 20147006]

36. Brueton VC, Tierney J, Stenning S, Harding S, Meredith S, Nazareth I, et al. Strategies to improve retention in randomised trials. Cochrane Database Syst Rev 2013 Dec;12:MR000032 [FREE Full text] [doi: 10.1002/14651858.MR000032.pub2] [Medline: 24297482]

37. Jadad A, Enkin M. Randomised Controlled Trials: Questions, Answers and Musings, 2nd Edition. Malden, MA: BMJ Books; 2007.

38. Gambino C, Acosta Y, Grieco E. English-Speaking Ability of the Foreign-Born Population in the United States: 2012. Washington, DC: US Census Bureau; 2014. URL: https://www.census.gov/library/publications/2014/acs/acs-26.html [accessed 2016-09-11] [WebCite Cache ID 6gh56itFY]

39. Department of Immigration Border Protection. The People of Australia: Statistics from the 2011 Census. Canberra, Australia: Commonwealth of Australia; 2014.

40. Gill PS, Shankar A, Quirke T, Freemantle N. Access to interpreting services in England: secondary analysis of national data. BMC Public Health 2009;9:12 [FREE Full text] [doi: 10.1186/1471-2458-9-12] [Medline: 19138392]

41. Mainous AG, Baker R, Majeed A, Koopman RJ, Everett CJ, Saxena S, et al. English language skills and diabetes and hypertension among foreign-born South Asian adults in England. Public Health Rep 2006;121(3):331-336 [FREE Full text] [Medline: $\underline{16640158]}$

42. Isaacs T, Laurier MD, Turner CE, Segalowitz N. Identifying second language speech tasks and ability levels for successful nurse oral interaction with patients in a linguistic minority setting: an instrument development project. Health Commun 2011 Sep;26(6):560-570. [doi: 10.1080/10410236.2011.558336] [Medline: 21512923]

43. Hussain-Gambles M, Atkin K, Leese B. South Asian participation in clinical trials: the views of lay people and health professionals. Health Policy 2006 Jul;77(2):149-165. [doi: 10.1016/j.healthpol.2005.07.022] [Medline: 16216378]

44. The Cochrane Collaboration. Cochrane Handbook for Systematic Reviews of Interventions. 2011. URL: http://handbook. cochrane.org/ [accessed 2016-11-09] [WebCite Cache ID 6gsoXE5yk]

45. Liberati A, Altman DG, Tetzlaff J, Mulrow C, Gøtzsche PC, Ioannidis JP, et al. The PRISMA statement for reporting systematic reviews and meta-analyses of studies that evaluate health care interventions: explanation and elaboration. PLoS Med 2009 Jul 21;6(7):e1000100 [FREE Full text] [doi: 10.1371/journal.pmed.1000100] [Medline: 19621070]

46. Edwards L, Rooshenas L, Isaacs T. Inclusion of ethnic minorities in telehealth trials for type 2 diabetes: protocol for a systematic review examining prevalence and language issues. JMIR Res Protoc 2016;5(1):e43 [FREE Full text] [doi: 10.2196/resprot.5195] [Medline: 26969340]

47. Huang Z, Tao H, Meng Q, Jing L. Management of endocrine disease. Effects of telecare intervention on glycemic control in type 2 diabetes: a systematic review and meta-analysis of randomized controlled trials. Eur J Endocrinol 2015

Mar;172(3):R93-R101 [FREE Full text] [doi: 10.1530/EJE-14-0441] [Medline: 25227131] 
48. Marcolino MS, Maia JX, Alkmim MB, Boersma E, Ribeiro AL. Telemedicine application in the care of diabetes patients: systematic review and meta-analysis. PLoS One 2013;8(11):e79246 [FREE Full text] [doi: 10.1371/journal.pone.0079246] [Medline: 24250826]

49. Higgins JP, Altman DG, Gøtzsche PC, Jüni P, Moher D, Oxman AD, Cochrane Bias Methods Group, Cochrane Statistical Methods Group. The Cochrane Collaboration's tool for assessing risk of bias in randomised trials. BMJ 2011;343:d5928 [FREE Full text] [Medline: 22008217]

50. The Leadership Conference Education Fund. Race and Ethnicity in the 2020 Census: Improving Data to Capture a Multiethnic America. Washington, DC: The Leadership Conference Education Fund; 2014.

51. 2011 Census: Ethnic Group, Local Authorities in the United Kingdom Database on the Internet. 2011. Table KS201UK URL: http://webarchive.nationalarchives.gov.uk/20160105160709/http://www.ons.gov.uk/ons/rel/census/2011-census/ key-statistics-and-quick-statistics-for-local-authorities-in-the-united-kingdom---part-1/rft-ks201uk.xls [accessed 2016-04-12] [WebCite Cache ID 6giNGVC94]

52. Popay J, Roberts H, Sowden A, Petticrew M, Arai L, Rodgers M. Guidance on the Conduct of Narrative Synthesis in Systematic Reviews: A Product from the ESRC Methods Programme. Lancaster: Lancaster University; 2006.

53. United States Census Bureau. 2016. Quick facts: United States URL: https://www.census.gov/quickfacts/table/PST045215/ $\underline{00}$ [accessed 2016-09-11] [WebCite Cache ID 6kRMXdd6B]

54. Adepoju O, Bolin J, Phillips C, Zhao H, Ohsfeldt R, McMaughan D, et al. Effects of diabetes self-management programs on time-to-hospitalization among patients with type 2 diabetes: a survival analysis model. Patient Educ Couns 2014 Apr;95(1):111-117 [FREE Full text] [doi: 10.1016/j.pec.2014.01.001] [Medline: 24468198]

55. Amoako E, Skelly A. Managing uncertainty in diabetes: an intervention for older African American women. Ethn Dis 2007;17(3):515-521. [Medline: 17985507]

56. Calderón JL, Shaheen M, Hays RD, Fleming ES, Norris KC, Baker RS. Improving Diabetes Health Literacy by Animation. Diabetes Educ 2014 Mar 27;40(3):361-372. [doi: 10.1177/0145721714527518] [Medline: 24676274]

57. Carter EL, Nunlee-Bland G, Callender C. A patient-centric, provider-assisted diabetes telehealth self-management intervention for urban minorities. Perspect Health Inf Manag 2011;8:1b [FREE Full text] [Medline: 21307985]

58. Crowley MJ, Powers BJ, Olsen MK, Grubber JM, Koropchak C, Rose CM, et al. The Cholesterol, Hypertension, And Glucose Education (CHANGE) study: results from a randomized controlled trial in African Americans with diabetes. Am Heart J 2013 Jul;166(1):179-186. [doi: 10.1016/j.ahj.2013.04.004] [Medline: 23816038]

59. Forjuoh SN, Bolin JN, Huber JC, Vuong AM, Adepoju OE, Helduser JW, et al. Behavioral and technological interventions targeting glycemic control in a racially/ethnically diverse population: a randomized controlled trial. BMC Public Health 2014;14:71 [FREE Full text] [doi: 10.1186/1471-2458-14-71] [Medline: 24450992]

60. Gary TL, Batts-Turner M, Yeh H, Hill-Briggs F, Bone LR, Wang N, et al. The effects of a nurse case manager and a community health worker team on diabetic control, emergency department visits, and hospitalizations among urban African Americans with type 2 diabetes mellitus: a randomized controlled trial. Arch Intern Med 2009 Oct 26;169(19):1788-1794. [doi: 10.1001/archinternmed.2009.338] [Medline: 19858437]

61. Heisler M, Choi H, Palmisano G, Mase R, Richardson C, Fagerlin A, et al. Comparison of community health worker-led diabetes medication decision-making support for low-income Latino and African American adults with diabetes using e-health tools versus print materials: a randomized, controlled trial. Ann Intern Med 2014 Nov 18;161(10 Suppl):S13-S22 [FREE Full text] [doi: 10.7326/M13-3012] [Medline: 25402398]

62. Long JA, Jahnle EC, Richardson DM, Loewenstein G, Volpp KG. Peer mentoring and financial incentives to improve glucose control in African American veterans: a randomized trial. Ann Intern Med 2012 Mar 20;156(6):416-424 [FREE Full text] [doi: 10.7326/0003-4819-156-6-201203200-00004] [Medline: 22431674]

63. Lorig K, Ritter PL, Laurent DD, Plant K, Green M, Jernigan VB, et al. Online diabetes self-management program: a randomized study. Diabetes Care 2010 Jun;33(6):1275-1281 [FREE Full text] [doi: 10.2337/dc09-2153] [Medline: 20299481]

64. Lorig K, Ritter PL, Villa F, Piette JD. Spanish diabetes self-management with and without automated telephone reinforcement: two randomized trials. Diabetes Care 2008 Mar;31(3):408-414. [doi: 10.2337/dc07-1313] [Medline: 18096810]

65. Ruggiero L, Riley BB, Hernandez R, Quinn LT, Gerber BS, Castillo A, et al. Medical assistant coaching to support diabetes self-care among low-income racial/ethnic minority populations: randomized controlled trial. West J Nurs Res 2014 Oct;36(9):1052-1073 [FREE Full text] [doi: 10.1177/0193945914522862] [Medline: 24569698]

66. Shea S, Weinstock RS, Starren J, Teresi J, Palmas W, Field L, et al. A randomized trial comparing telemedicine case management with usual care in older, ethnically diverse, medically underserved patients with diabetes mellitus. J Am Med Inform Assoc 2006;13(1):40-51 [FREE Full text] [doi: 10.1197/jamia.M1917] [Medline: 16221935]

67. Sacco WP, Bykowski CA, Mayhew LL, White KE. Educational attainment moderates the effect of a brief diabetes self-care intervention. Diabetes Res Clin Pract 2012 Jan;95(1):62-67. [doi: 10.1016/j.diabres.2011.08.027] [Medline: 21992869]

68. Sacco WP, Malone JI, Morrison AD, Friedman A, Wells K. Effect of a brief, regular telephone intervention by paraprofessionals for type 2 diabetes. J Behav Med 2009 Aug;32(4):349-359. [doi: 10.1007/s10865-009-9209-4] [Medline: $\underline{19365719]}$ 
69. McMahon GT, Fonda SJ, Gomes HE, Alexis G, Conlin PR. A randomized comparison of online- and telephone-based care management with internet training alone in adult patients with poorly controlled type 2 diabetes. Diabetes Technol Ther 2012 Nov;14(11):1060-1067 [FREE Full text] [doi: 10.1089/dia.2012.0137] [Medline: 22953754]

70. Davis RM, Hitch AD, Salaam MM, Herman WH, Zimmer-Galler IE, Mayer-Davis EJ. TeleHealth improves diabetes self-management in an underserved community: diabetes TeleCare. Diabetes Care 2010 Aug;33(8):1712-1717 [FREE Full text] [doi: 10.2337/dc09-1919] [Medline: 20484125]

71. Dy P, Morin PC, Weinstock RS. Use of telemedicine to improve glycemic management in a skilled nursing facility: a pilot study. Telemed J E Health 2013 Aug;19(8):643-645. [doi: 10.1089/tmj.2012.0274] [Medline: 23758078]

72. Glasgow RE, Strycker LA, King DK, Toobert DJ, Rahm AK, Jex M, et al. Robustness of a computer-assisted diabetes self-management intervention across patient characteristics, healthcare settings, and intervention staff. Am J Manag Care 2006 Mar;12(3):137-145 [FREE Full text] [Medline: 16524346]

73. Glasgow RE, Toobert DJ. Brief, computer-assisted diabetes dietary self-management counseling: effects on behavior, physiologic outcomes, and quality of life. Med Care 2000 Nov;38(11):1062-1073. [Medline: 11078048]

74. Glasgow RE, Toobert DJ, Hampson SE, Strycker LA. Implementation, generalization and long-term results of the "choosing well" diabetes self-management intervention. Patient Educ Couns 2002;48(2):115-122. [Medline: 12401414]

75. Khan MA, Shah S, Grudzien A, Onyejekwe N, Banskota P, Karim S, et al. A diabetes education multimedia program in the waiting room setting. Diabetes Ther 2011 Sep;2(3):178-188 [FREE Full text] [doi: 10.1007/s13300-011-0007-y] [Medline: 22127826]

76. King DK, Estabrooks PA, Strycker LA, Toobert DJ, Bull SS, Glasgow RE. Outcomes of a multifaceted physical activity regimen as part of a diabetes self-management intervention. Ann Behav Med 2006 Apr;31(2):128-137. [doi: 10.1207/s15324796abm3102 4] [Medline: 16542127$]$

77. Nagrebetsky A, Larsen M, Craven A, Turner J, McRobert N, Murray E, et al. Stepwise self-titration of oral glucose-lowering medication using a mobile telephone-based telehealth platform in type 2 diabetes: a feasibility trial in primary care. $\mathbf{J}$ Diabetes Sci Technol 2013;7(1):123-134 [FREE Full text] [Medline: 23439168]

78. Piette JD, Resnicow K, Choi H, Heisler M. A diabetes peer support intervention that improved glycemic control: mediators and moderators of intervention effectiveness. Chronic Illn 2013 Dec;9(4):258-267 [FREE Full text] [doi: 10.1177/1742395313476522] [Medline: 23585636]

79. Pressman AR, Kinoshita L, Kirk S, Barbosa GM, Chou C, Minkoff J. A novel telemonitoring device for improving diabetes control: protocol and results from a randomized clinical trial. Telemed J E Health 2014 Feb;20(2):109-114. [doi: 10.1089/tmj.2013.0157] [Medline: 24404816]

80. Stone RA, Sevick MA, Rao RH, Macpherson DS, Cheng C, Kim S, et al. The Diabetes Telemonitoring Study Extension: an exploratory randomized comparison of alternative interventions to maintain glycemic control after withdrawal of diabetes home telemonitoring. J Am Med Inform Assoc 2012;19(6):973-979 [FREE Full text] [doi: 10.1136/amiajnl-2012-000815] [Medline: 22610495]

81. Tildesley HD, Mazanderani AB, Ross SA. Effect of Internet therapeutic intervention on A1C levels in patients with type 2 diabetes treated with insulin. Diabetes Care 2010 Aug;33(8):1738-1740 [FREE Full text] [doi: 10.2337/dc09-2256] [Medline: 20668152]

82. Tildesley HD, Wright AM, Chan JH, Mazanderani AB, Ross SA, Tildesley HG, et al. A comparison of internet monitoring with continuous glucose monitoring in insulin-requiring type 2 diabetes mellitus. Can J Diabetes 2013 Oct;37(5):305-308. [doi: 10.1016/j.jcjd.2013.05.006] [Medline: 24500556]

83. Whitlock WL, Brown A, Moore K, Pavliscsak H, Dingbaum A, Lacefield D, et al. Telemedicine improved diabetic management. Mil Med 2000 Aug;165(8):579-584. [Medline: 10957848]

84. Pacaud D, Kelley H, Downey A, Chiasson M. Successful delivery of diabetes self-care education and follow-up through eHealth media. Can J Diabetes 2012 Oct;36(5):257-262. [doi: 10.1016/j.jcjd.2012.08.006]

85. Quinn CC, Clough SS, Minor JM, Lender D, Okafor MC, Gruber-Baldini A. WellDoc mobile diabetes management randomized controlled trial: change in clinical and behavioral outcomes and patient and physician satisfaction. Diabetes Technol Ther 2008 Jun;10(3):160-168. [doi: 10.1089/dia.2008.0283] [Medline: 18473689]

86. Tang TS, Digby EM, Wright AM, Chan JH, Mazanderani AB, Ross SA, et al. Real-time continuous glucose monitoring versus internet-based blood glucose monitoring in adults with type 2 diabetes: a study of treatment satisfaction. Diabetes Res Clin Pract 2014 Dec;106(3):481-486. [doi: 10.1016/j.diabres.2014.09.050] [Medline: 25458333]

87. Quinn CC, Shardell MD, Terrin ML, Barr EA, Ballew SH, Gruber-Baldini AL. Cluster-randomized trial of a mobile phone personalized behavioral intervention for blood glucose control. Diabetes Care 2011 Sep;34(9):1934-1942 [FREE Full text] [doi: 10.2337/dc11-0366] [Medline: 21788632]

88. Timmerberg BD, Wurst J, Patterson J, Spaulding RJ, Belz NE. Feasibility of using videoconferencing to provide diabetes education: a pilot study. J Telemed Telecare 2009;15(2):95-97. [doi: 10.1258/jtt.2008.080813] [Medline: 19246610]

89. Shreck E, Gonzalez JS, Cohen HW, Walker EA. Risk perception and self-management in urban, diverse adults with type 2 diabetes: the improving diabetes outcomes study. Int J Behav Med 2014 Feb;21(1):88-98 [FREE Full text] [doi: 10.1007/s12529-013-9291-4] [Medline: 23385488] 
90. Long AF, Gambling T, Young RJ, Taylor J, Mason JM. Acceptability and satisfaction with a telecarer approach to the management of type 2 diabetes. Diabetes Care 2005 Feb;28(2):283-289. [Medline: 15677780]

91. Dale J, Caramlau I, Sturt J, Friede T, Walker R. Telephone peer-delivered intervention for diabetes motivation and support: the telecare exploratory RCT. Patient Educ Couns 2009 Apr;75(1):91-98. [doi: 10.1016/j.pec.2008.09.014] [Medline: 19013741]

92. Eakin EG, Reeves MM, Winkler E, Healy GN, Dunstan DW, Owen N, et al. Six-month outcomes from living well with diabetes: A randomized trial of a telephone-delivered weight loss and physical activity intervention to improve glycemic control. Ann Behav Med 2013 Oct;46(2):193-203. [doi: 10.1007/s12160-013-9498-2] [Medline: 23609340]

93. Glasgow RE, Kurz D, King D, Dickman JM, Faber AJ, Halterman E, et al. Outcomes of minimal and moderate support versions of an internet-based diabetes self-management support program. J Gen Intern Med 2010 Dec;25(12):1315-1322 [FREE Full text] [doi: 10.1007/s11606-010-1480-0] [Medline: 20714820]

94. Glasgow RE, Kurz D, King D, Dickman JM, Faber AJ, Halterman E, et al. Twelve-month outcomes of an Internet-based diabetes self-management support program. Patient Educ Couns 2012 Apr;87(1):81-92 [FREE Full text] [doi: 10.1016/j.pec.2011.07.024] [Medline: 21924576]

95. Hunt CW, Sanderson BK, Ellison KJ. Support for diabetes using technology: a pilot study to improve self-management. Medsurg Nurs 2014;23(4):231-237. [Medline: 25318336]

96. Piette JD, Richardson C, Himle J, Duffy S, Torres T, Vogel M, et al. A randomized trial of telephonic counseling plus walking for depressed diabetes patients. Med Care 2011 Jul;49(7):641-648 [FREE Full text] [doi: 10.1097/MLR.0b013e318215d0c9] [Medline: 21478777]

97. Varney JE, Weiland TJ, Inder WJ, Jelinek GA. Effect of hospital-based telephone coaching on glycaemic control and adherence to management guidelines in type 2 diabetes, a randomised controlled trial. Intern Med J 2014 Sep;44(9):890-897. [doi: 10.1111/imj.12515] [Medline: 24963611]

98. Grant RW, Wald JS, Schnipper JL, Gandhi TK, Poon EG, Orav EJ, et al. Practice-linked online personal health records for type 2 diabetes mellitus: a randomized controlled trial. Arch Intern Med 2008 Sep 8;168(16):1776-1782 [FREE Full text] [doi: 10.1001/archinte.168.16.1776] [Medline: 18779465$]$

99. Holbrook A, Thabane L, Keshavjee K, Dolovich L, Bernstein B, Chan D, et al. Individualized electronic decision support and reminders to improve diabetes care in the community: COMPETE II randomized trial. CMAJ 2009 Jul 7;181(1-2):37-44 [FREE Full text] [doi: 10.1503/cmaj.081272] [Medline: 19581618]

100. Izquierdo R, Meyer S, Starren J, Goland R, Teresi J, Shea S, et al. Detection and remediation of medically urgent situations using telemedicine case management for older patients with diabetes mellitus. Ther Clin Risk Manag 2007 Jun;3(3):485-489 [FREE Full text] [Medline: 18488079]

101. Ralston JD, Hirsch IB, Hoath J, Mullen M, Cheadle A, Goldberg HI. Web-based collaborative care for type 2 diabetes: a pilot randomized trial. Diabetes Care 2009 Feb;32(2):234-239 [FREE Full text] [doi: 10.2337/dc08-1220] [Medline: 19017773]

102. Shea S, Kothari D, Teresi JA, Kong J, Eimicke JP, Lantigua RA, et al. Social impact analysis of the effects of a telemedicine intervention to improve diabetes outcomes in an ethnically diverse, medically underserved population: findings from the IDEATel Study. Am J Public Health 2013 Oct;103(10):1888-1894. [doi: 10.2105/AJPH.2012.300909] [Medline: 23488491]

103. Tang PC, Overhage JM, Chan AS, Brown NL, Aghighi B, Entwistle MP, et al. Online disease management of diabetes: engaging and motivating patients online with enhanced resources-diabetes (EMPOWER-D), a randomized controlled trial. J Am Med Inform Assoc 2013 May 1;20(3):526-534 [FREE Full text] [doi: 10.1136/amiajnl-2012-001263] [Medline: 23171659]

104. Wakefield BJ, Holman JE, Ray A, Scherubel M, Adams MR, Hillis SL, et al. Effectiveness of home telehealth in comorbid diabetes and hypertension: a randomized, controlled trial. Telemed J E Health 2011 May;17(4):254-261. [doi: 10.1089/tmj.2010.0176] [Medline: 21476945]

105. Walker EA, Shmukler C, Ullman R, Blanco E, Scollan-Koliopoulus M, Cohen HW. Results of a successful telephonic intervention to improve diabetes control in urban adults: a randomized trial. Diabetes Care 2011 Jan;34(1):2-7 [FREE Full text] [doi: 10.2337/dc10-1005] [Medline: 21193619]

106. Anderson DR, Christison-Lagay J, Villagra V, Liu H, Dziura J. Managing the space between visits: a randomized trial of disease management for diabetes in a community health center. J Gen Intern Med 2010 Oct;25(10):1116-1122 [FREE Full text] [doi: 10.1007/s11606-010-1419-5] [Medline: 20556536]

107. Shea S, Weinstock RS, Teresi JA, Palmas W, Starren J, Cimino JJ, et al. A randomized trial comparing telemedicine case management with usual care in older, ethnically diverse, medically underserved patients with diabetes mellitus: 5 year results of the IDEATel study. J Am Med Inform Assoc 2009;16(4):446-456 [FREE Full text] [doi: 10.1197/jamia.M3157] [Medline: 19390093]

108. McKay HG, King D, Eakin EG, Seeley JR, Glasgow RE. The diabetes network internet-based physical activity intervention: a randomized pilot study. Diabetes Care 2001 Aug;24(8):1328-1334. [Medline: 11473065]

109. Richardson CR, Mehari KS, McIntyre LG, Janney AW, Fortlage LA, Sen A, et al. A randomized trial comparing structured and lifestyle goals in an internet-mediated walking program for people with type 2 diabetes. Int J Behav Nutr Phys Act 2007;4:59 [FREE Full text] [doi: 10.1186/1479-5868-4-59] [Medline: 18021411] 
110. Arora S, Peters AL, Burner E, Lam CN, Menchine M. Trial to examine text message-based mHealth in emergency department patients with diabetes (TExT-MED): a randomized controlled trial. Ann Emerg Med 2014 Jun;63(6):745-754.e6. [doi: 10.1016/j.annemergmed.2013.10.012] [Medline: 24225332]

111. Frosch DL, Uy V, Ochoa S, Mangione CM. Evaluation of a behavior support intervention for patients with poorly controlled diabetes. Arch Intern Med 2011 Dec 12;171(22):2011-2017. [doi: 10.1001/archinternmed.2011.497] [Medline: 21986347]

112. Glasgow RE, Nutting PA, Toobert DJ, King DK, Strycker LA, Jex M, et al. Effects of a brief computer-assisted diabetes self-management intervention on dietary, biological and quality-of-life outcomes. Chronic Illn 2006 Mar;2(1):27-38. [Medline: 17175680$]$

113. Graziano JA, Gross CR. A randomized controlled trial of an automated telephone intervention to improve glycemic control in type 2 diabetes. ANS Adv Nurs Sci 2009;32(3):e42-e57. [doi: 10.1097/ANS.0b013e3181b117a9] [Medline: 19707086]

114. Huizinga MM, Gebretsadik T, Garcia UC, Shintani AK, Michon SR, Shackleford LO, et al. Preventing glycaemic relapse in recently controlled type 2 diabetes patients: a randomised controlled trial. Diabetologia 2010 May;53(5):832-839 [FREE Full text] [doi: 10.1007/s00125-010-1658-3] [Medline: 20084363]

115. Izquierdo R, Lagua CT, Meyer S, Ploutz-Snyder RJ, Palmas W, Eimicke JP, et al. Telemedicine intervention effects on waist circumference and body mass index in the IDEATel project. Diabetes Technol Ther 2010 Mar;12(3):213-220. [doi: 10.1089/dia.2009.0102] [Medline: 20151772]

116. Krein SL, Klamerus ML, Vijan S, Lee JL, Fitzgerald JT, Pawlow A, et al. Case management for patients with poorly controlled diabetes: a randomized trial. Am J Med 2004 Jun 1;116(11):732-739. [doi: 10.1016/j.amjmed.2003.11.028] [Medline: 15144909$]$

117. Piette JD, Valenstein M, Himle J, Duffy S, Torres T, Vogel M, et al. Clinical complexity and the effectiveness of an intervention for depressed diabetes patients. Chronic Illn 2011 Dec;7(4):267-278 [FREE Full text] [doi: 10.1177/1742395311409259] [Medline: 21840915]

118. Schillinger D, Hammer H, Wang F, Palacios J, McLean I, Tang A, et al. Seeing in 3-D: examining the reach of diabetes self-management support strategies in a public health care system. Health Educ Behav 2008 Oct;35(5):664-682. [doi: 10.1177/1090198106296772] [Medline: 17513690]

119. Sevick MA, Korytkowski M, Stone RA, Piraino B, Ren D, Sereika S, et al. Biophysiologic outcomes of the Enhancing Adherence in Type 2 Diabetes (ENHANCE) trial. J Acad Nutr Diet 2012 Aug;112(8):1147-1157 [FREE Full text] [doi: 10.1016/j.jand.2012.05.008] [Medline: 22818724]

120. Shea S, IDEATel Consortium. The Informatics for Diabetes and Education Telemedicine (IDEATel) project. Trans Am Clin Climatol Assoc 2007;118:289-304 [FREE Full text] [Medline: 18528511]

121. Stone RA, Rao RH, Sevick MA, Cheng C, Hough LJ, Macpherson DS, et al. Active care management supported by home telemonitoring in veterans with type 2 diabetes: the DiaTel randomized controlled trial. Diabetes Care 2010 Mar;33(3):478-484 [FREE Full text] [doi: 10.2337/dc09-1012] [Medline: 20009091]

122. Trief PM, Izquierdo R, Eimicke JP, Teresi JA, Goland R, Palmas W, et al. Adherence to diabetes self care for white, African-American and Hispanic American telemedicine participants: 5 year results from the IDEATel project. Ethn Health 2013;18(1):83-96. [doi: 10.1080/13557858.2012.700915] [Medline: 22762449]

123. Trief PM, Morin PC, Izquierdo R, Teresi J, Eimicke JP, Goland R, et al. Depression and glycemic control in elderly ethnically diverse patients with diabetes: the IDEATel project. Diabetes Care 2006 Apr;29(4):830-835. [Medline: 16567823]

124. Trief PM, Teresi JA, Eimicke JP, Shea S, Weinstock RS. Improvement in diabetes self-efficacy and glycaemic control using telemedicine in a sample of older, ethnically diverse individuals who have diabetes: the IDEATel project. Age Ageing 2009 Mar;38(2):219-225 [FREE Full text] [doi: 10.1093/ageing/afn299] [Medline: 19171951]

125. Trief PM, Teresi JA, Izquierdo R, Morin PC, Goland R, Field L, et al. Psychosocial outcomes of telemedicine case management for elderly patients with diabetes: the randomized IDEATel trial. Diabetes Care 2007 May;30(5):1266-1268. [doi: 10.2337/dc06-2476] [Medline: 17325261]

126. Wakefield BJ, Holman JE, Ray A, Scherubel M, Adams MR, Hills SL, et al. Outcomes of a home telehealth intervention for patients with diabetes and hypertension. Telemed J E Health 2012 Oct;18(8):575-579. [doi: 10.1089/tmj.2011.0237] [Medline: 22873700]

127. Wakefield BJ, Koopman RJ, Keplinger LE, Bomar M, Bernt B, Johanning JL, et al. Effect of home telemonitoring on glycemic and blood pressure control in primary care clinic patients with diabetes. Telemed J E Health 2014 Mar;20(3):199-205 [FREE Full text] [doi: 10.1089/tmj.2013.0151] [Medline: 24404819]

128. Weinstock RS, Brooks G, Palmas W, Morin PC, Teresi JA, Eimicke JP, et al. Lessened decline in physical activity and impairment of older adults with diabetes with telemedicine and pedometer use: results from the IDEATel study. Age Ageing 2011 Jan;40(1):98-105 [FREE Full text] [doi: 10.1093/ageing/afq147] [Medline: 21081539]

129. Weinstock RS, Teresi JA, Goland R, Izquierdo R, Palmas W, Eimicke JP, et al. Glycemic control and health disparities in older ethnically diverse underserved adults with diabetes: five-year results from the Informatics for Diabetes Education and Telemedicine (IDEATel) study. Diabetes Care 2011 Feb;34(2):274-279 [FREE Full text] [doi: 10.2337/dc10-1346] [Medline: 21270184]

130. Luchsinger JA, Palmas W, Teresi JA, Silver S, Kong J, Eimicke JP, et al. Improved diabetes control in the elderly delays global cognitive decline. J Nutr Health Aging 2011 Jun;15(6):445-449 [FREE Full text] [Medline: 21623465] 
131. Barrera M, Glasgow RE, McKay HG, Boles SM, Feil EG. Do Internet-based support interventions change perceptions of social support?: An experimental trial of approaches for supporting diabetes self-management. Am J Community Psychol 2002 Oct;30(5):637-654. [Medline: 12188054]

132. Blackberry ID, Furler JS, Best JD, Chondros P, Vale M, Walker C, et al. Effectiveness of general practice based, practice nurse led telephone coaching on glycaemic control of type 2 diabetes: the Patient Engagement and Coaching for Health (PEACH) pragmatic cluster randomised controlled trial. BMJ 2013;347:f5272 [FREE Full text] [Medline: 24048296]

133. Dyson PA, Beatty S, Matthews DR. An assessment of lifestyle video education for people newly diagnosed with type 2 diabetes. J Hum Nutr Diet 2010 Aug;23(4):353-359. [doi: 10.1111/j.1365-277X.2010.01077.x] [Medline: 20497292]

134. Faridi Z, Liberti L, Shuval K, Northrup V, Ali A, Katz DL. Evaluating the impact of mobile telephone technology on type 2 diabetic patients' self-management: the NICHE pilot study. J Eval Clin Pract 2008 Jun;14(3):465-469. [doi: 10.1111/j.1365-2753.2007.00881.x] [Medline: 18373577]

135. Gibson B, Marcus RL, Staggers N, Jones J, Samore M, Weir C. Efficacy of a computerized simulation in promoting walking in individuals with diabetes. J Med Internet Res 2012;14(3):e71 [FREE Full text] [doi: 10.2196/jmir.1965] [Medline: 22576226]

136. Glasgow RE, Boles SM, McKay HG, Feil EG, Barrera M. The D-Net diabetes self-management program: long-term implementation, outcomes, and generalization results. Prev Med 2003 Apr;36(4):410-419. [Medline: 12649049]

137. Jennings CA, Vandelanotte C, Caperchione CM, Mummery WK. Effectiveness of a web-based physical activity intervention for adults with Type 2 diabetes-a randomised controlled trial. Prev Med 2014 Mar;60:33-40. [doi: 10.1016/j.ypmed.2013.12.011] [Medline: 24345601]

138. McKay HG, Glasgow RE, Feil EG, Boles SM, Barrera MJ. Internet-based diabetes self-management and support: initial outcomes from the Diabetes Network project. Rehabil Psychol 2002;47(1):31-48. [doi: 10.1037//0090-5550.47.1.31]

139. Odegard PS, Christensen DB. MAP study: RCT of a medication adherence program for patients with type 2 diabetes. J Am Pharm Assoc (2003) 2012;52(6):753-762. [doi: 10.1331/JAPhA.2012.11001] [Medline: 23229961]

140. Tildesley H, Mazanderani A, Chan J, Ross S. Efficacy of A1C reduction using Internet intervention in patients with type 2 diabetes treated with insulin. Can J Diabetes 2011 Jan;35(3):250-253. [doi: 10.1016/S1499-2671(11)53007-2]

141. Vigersky RA, Fonda SJ, Chellappa M, Walker MS, Ehrhardt NM. Short- and long-term effects of real-time continuous glucose monitoring in patients with type 2 diabetes. Diabetes Care 2012 Jan;35(1):32-38 [FREE Full text] [doi: 10.2337/dc11-1438] [Medline: 22100963]

142. Williams ED, Bird D, Forbes AW, Russell A, Ash S, Friedman R, et al. Randomised controlled trial of an automated, interactive telephone intervention (TLC Diabetes) to improve type 2 diabetes management: baseline findings and six-month outcomes. BMC Public Health 2012;12:602 [FREE Full text] [doi: 10.1186/1471-2458-12-602] [Medline: 22857017]

143. Young RJ, Taylor J, Friede T, Hollis S, Mason JM, Lee P, et al. Pro-active call center treatment support (PACCTS) to improve glucose control in type 2 diabetes: a randomized controlled trial. Diabetes Care 2005 Feb;28(2):278-282. [Medline: 15677779]

144. Liebreich T, Plotnikoff RC, Courneya KS, Boulé N. Diabetes NetPLAY: a physical activity website and linked email counselling randomized intervention for individuals with type 2 diabetes. Int J Behav Nutr Phys Act 2009;6:18 [FREE Full text] [doi: 10.1186/1479-5868-6-18] [Medline: 19327141]

145. Cumming A. Language assessment in education: tests, curricula, and teaching. Ann Rev Appl Linguist 2009 Apr 24;29:90-100. [doi: 10.1017/S0267190509090084]

146. Hughson J, Woodward-Kron R, Parker A, Hajek J, Bresin A, Knoch U, et al. A review of approaches to improve participation of culturally and linguistically diverse populations in clinical trials. Trials 2016 May;17(1):263 [FREE Full text] [doi: 10.1186/s13063-016-1384-3] [Medline: 27229153]

147. Central Intelligence Agency. The World Factbook. Washington, DC: Central Intelligence Agency; 2013. URL: https://www. cia.gov/library/publications/the-world-factbook/fields/2075.html [accessed 2016-04-19] [WebCite Cache ID 6gtAe8gZI]

148. National Insitutes of Health. 2001. NIH policy and guidelines on the inclusion of women and minorities as subjects in clinical research: amended, October, 2001 URL: http://grants.nih.gov/grants/funding/women_min/ guidelines amended 10 2001.htm[WebCite Cache ID 6gsnkYZ6K]

149. Kanter MH, Abrams KM, Carrasco MR, Spiegel NH, Vogel RS, Coleman KJ. Patient-physician language concordance: a strategy for meeting the needs of spanish-speaking patients in primary care. Perm J 2009;13(4):79-84 [FREE Full text] [Medline: 20740108]

150. Segalowitz N, Kehayia E. Exploring the determinants of language barriers in health care (LBHC): toward a research agenda for the language sciences. Can Mod Lang Rev 2011 Nov;67(4):480-507. [doi: $10.3138 / \mathrm{cmlr} .67 .4 .480$ ]

151. Greenhalgh T. Health literacy: towards system level solutions. BMJ 2015;350:h1026. [Medline: 25712067]

152. Bibi R, Redwood S, Taheri S. Raising the issue of overweight and obesity with the South Asian community. Br J Gen Pract 2014 Aug;64(625):417-419 [FREE Full text] [doi: 10.3399/bjgp14X681145] [Medline: 25071053]

153. Donovan JL, Paramasivan S, de SI, Toerien M. Clear obstacles and hidden challenges: understanding recruiter perspectives in six pragmatic randomised controlled trials. Trials 2014;15:5 [FREE Full text] [doi: 10.1186/1745-6215-15-5] [Medline: 24393291] 
154. Schulz KF, Altman DG, Moher D. CONSORT 2010 statement: updated guidelines for reporting parallel group randomized trials. Ann Intern Med 2010 Jun 1;152(11):726-732. [doi: 10.7326/0003-4819-152-11-201006010-00232] [Medline: 20335313]

155. Trofimovich P, Isaacs T. Disentangling accent from comprehensibility. Bilingualism 2012 May 25;15(04):905-916. [doi: $10.1017 /$ S1366728912000168]

156. Derwing T, Munro M. Pronunciation Fundamentals: Evidence-Based Perspectives for L2 Teaching and Research. Amsterdam: John Benjamins Publishing Company; 2015.

157. Mills N, Blazeby JM, Hamdy FC, Neal DE, Campbell B, Wilson C, et al. Training recruiters to randomized trials to facilitate recruitment and informed consent by exploring patients' treatment preferences. Trials 2014;15:323 [FREE Full text] [doi: 10.1186/1745-6215-15-323] [Medline: 25115160]

\author{
Abbreviations \\ CONSORT: Consolidated Standards of Reporting Trials \\ $\mathbf{H b A}_{1 \mathbf{c}}$ : glycated hemoglobin \\ PRISMA: Preferred Reporting Items for Systematic Reviews and Meta-Analyses \\ RCT: randomized controlled trial \\ ROB: risk of bias
}

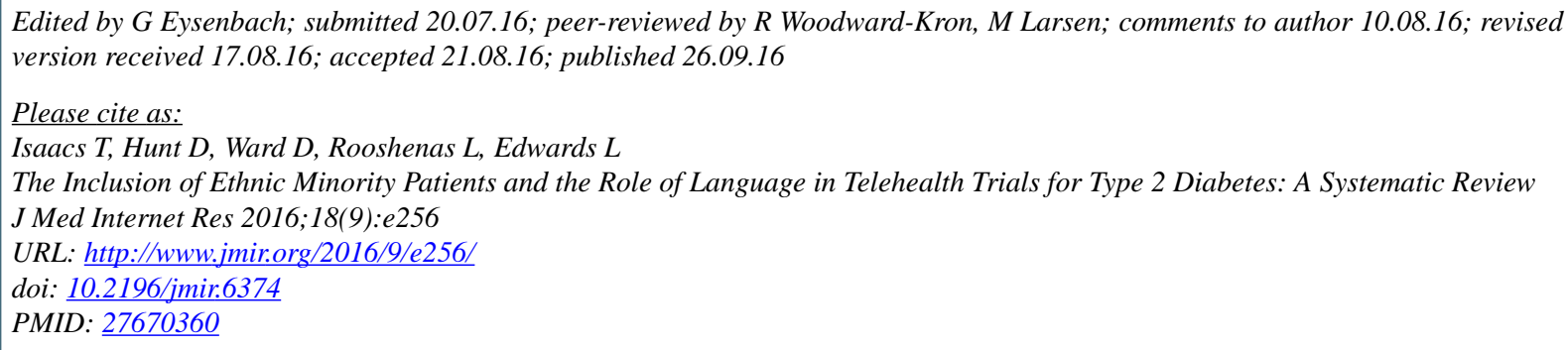

(CTalia Isaacs, Daniel Hunt, Danielle Ward, Leila Rooshenas, Louisa Edwards. Originally published in the Journal of Medical Internet Research (http://www.jmir.org), 26.09.2016. This is an open-access article distributed under the terms of the Creative Commons Attribution License (http://creativecommons.org/licenses/by/2.0/), which permits unrestricted use, distribution, and reproduction in any medium, provided the original work, first published in the Journal of Medical Internet Research, is properly cited. The complete bibliographic information, a link to the original publication on http://www.jmir.org/, as well as this copyright and license information must be included. 